\title{
Comparative Analysis of Writing Approaches Practised in Malaysian ESL Classrooms
}

\author{
Sarala Thulasi Palpanadan \\ Elizabeth M.Anthony \\ Nurizah Md Ngadiran \\ Hazila Kadir @Shahar \\ Centre for Language Studies \\ Universiti Tun Hussein Onn Malaysia \\ Ahmad Zainal \\ IPGK Temenggong Ibrahim \\ Johor, Malaysia.
}

\begin{abstract}
There is an enormous literature in the Malaysian schools' context that reveals writing skills deficiency in English among the students. Hence, this study conducted a comparative analysis of the two popular writing approaches (product approach and process approach) practised widely as writing instructions in the educational settings. A case study was conducted on the selected teachers to study their writing instructions in ESL classrooms. The investigation revealed that language teachers largely practice product writing approach. In addition, the paper also provides some insights that as compared to product writing approach, process writing approach is more effective. Process approach provides students more opportunities for independent writing, creative writing and evaluative writing which lead towards developing higher order thinking skills. Hence, this paper recommends that Malaysian schools should adopt strategies of process writing approach to teach English in ESL classrooms to produce students who can write more competently in future.
\end{abstract}

Keywords: writing instructions, Malaysian ESL classrooms, product versus process approach, comparative analysis

\subsection{Introduction}

There is an enormous literature in the context of Malaysian English as a Second Language (ESL) schools' that reveals writing skills deficiency among the students (Ramadi, Ramadi, \& Nasr, 2016; How et.al., 2015). As a matter of fact, Malaysian students are given exposure to English from Primary One through Form Five at secondary level and it is disappointing that despite this many students do not seem to be competent enough in the language. Students' poor performance was evident where they strive in the language at tertiary level where they struggle even go through the Malaysia University English Test (MUET) with the minimum requirements of their respective faculties (Hilmi, et al., 2010). Since many students were incompetent in the communicative activities especially in writing, they were found to struggle with English competency at tertiary levels be it engineering, information technology or even Teaching English as a Second Language (TESL) students. The reports, assignments, proposals, and many more written tasks prepared by the students show that the students are still grappling to write effectively let alone writing tests. In addition, the writing skills in English are important for students to master to confirm employability in future (Suryasa et al., 2017; Ting et al., 2017). Therefore, writing abilities need to inculcated among students as early as when they are in primary level to help them develop the skills accordingly with the passage of time before the students enter the job market.

Many teachers and lecturers are facing great challenges with effective writing instructions to conduct the writing lessons successfully (Pour-Mohammadi, Zainal \&Cheong, 2012). Learners require a considerable instruction in writing to become competent writers, and therefore, the nature of writing has to be scrutinized (Williamsa\&Beamb, 2019; Sahin, Bullock \& Stables, 2002). Teachers need to have sufficient knowledge on how to teach writing efficiently so that students can learn writing well. Thus, it very important to study the teaching strategies of teachers used in the writing classrooms and analyze the outcome of the lesson so that teachers can be in the know of effective instructions that can be practised to teach writing well in future. 


\subsection{Literature Review}

Among the approaches, the product approach and process approachwere mostly employed in the ESL writing instructions either as isolated approaches or as blended approach (Badger \& White, 2000;Hilmi et.al, 2010). Even though the approaches receive many compliments and critics, they are still widely practised in the arena of writing instructions in Malaysian context in all educational settings. Thus, it is important to study the writing strategies of the approaches selected by the teachers to be employed in the writing lessons to study its impacts on the students. Thus, the writing strategies will be studied based on the product approach and process approachbased on Steel's Model (2004). The product approach consists of 4 strategies (or stages): familiarization, controlled practice, guided writing, and free writing. Meanwhile the process approach consists of 8 strategies (or stages): brainstorming, planning, mind mapping, first draft, peer feedback, editing, final draft and evaluation and feedback.

The previous researchers indicated that Malaysian students faced much constraints in the area of language learning especially pertaining to writing skills due to the ineffective instructional methods used (Mukundan et al., 2013). Researchers have recommended process writing approach as a way to teach writing well(Al-Sawalha, 2014). It was obvious that the literature favoured process approach but the teacher trainees preferred to practice product approach for the convenience of the teaching purposes. Therefore, this study was conducted to explore the writing instructional issues in the selected primary ESL classrooms in the Malaysian context and its impact on the students.

\subsection{Research Objective}

This paper intends to study the pre-service teachers' preferred writing approaches by way of studying the strategies employed in detail. This paper hopes to highlight the current practices in writing instructions at primary level and suggest some strategies to be incorporated in the writing instructions as a way to enhance the students' writing abilities.

\subsection{Research Questions}

1. What teaching approach is preferred by the pre-service teachers to teach writing in the primary ESL classrooms?

2. What is the impact of using the selected writing approaches on the students in the primary ESL classrooms?

\subsection{Methodology}

This a case study which employed mixed method in nature. Data was collected from 10 pre-service TESL teachers who conducted writing lessons in English to primary students, aged nine to ten years old. The classes were observed using observation checklist. The students' written texts were also collected and analyzed to study the writing patterns that the students used in producing their written tasks. The observation checklists were analyzed using Rasch Measurement Model and the written texts were marked and analyzed thematically. The findings were triangulated to identify the preservice teachers' choice of writing instructions used in the class

\subsection{Analysis}

The findings of this study confirms that all the selected teacher trainees dominantly practised product approach in teaching writing in various teaching stages in the ESL primary classrooms. However, there were several issues were highlighted and discussed based on the findings and earlier research done on the practice of the writing approach employed in teaching English. The pre-service teachers' teaching approaches were investigated using the questionnaire prepared based on the two selected approaches. The questionnaire was tested using Rasch Measurement Model. The reading of alpha Cronbach showed 0.86 which proved that the questionnaire is reliable. However, further analysis has highlighted some misconceptions of the writing instructions based on the teaching approaches. Figure 1 shows the revisited Models of Steel (2004). 
Figure 1: The Frequency of Strategies Practised by Pre-service Teachers

Product Approach
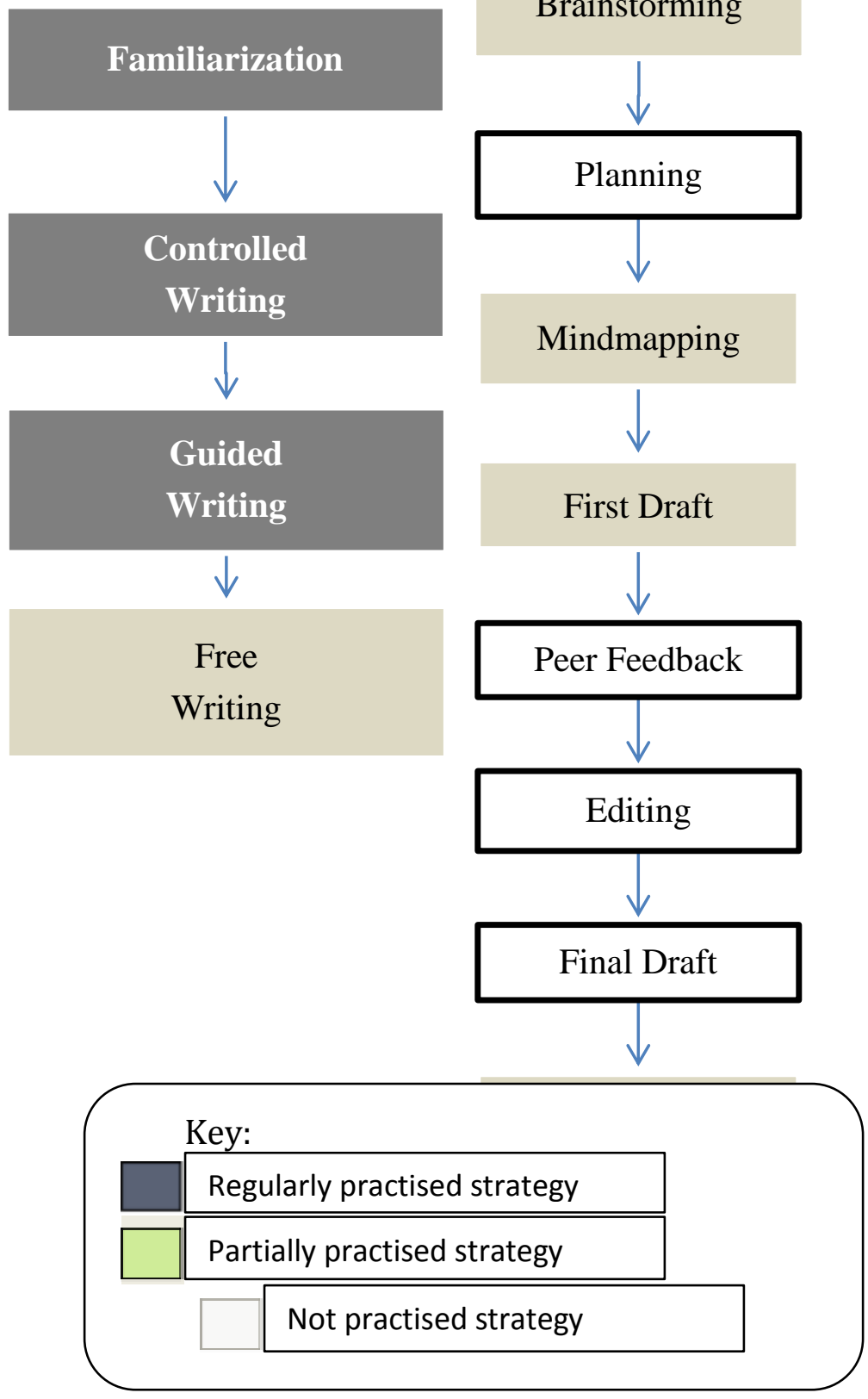

Process Approach

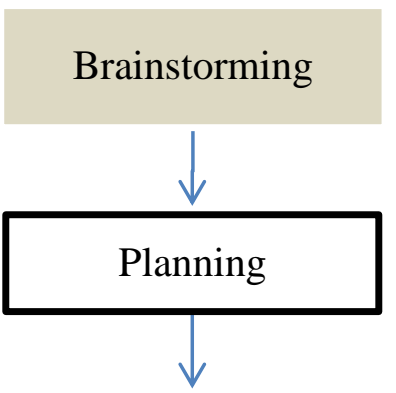

Mindmapping

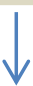

First Draft

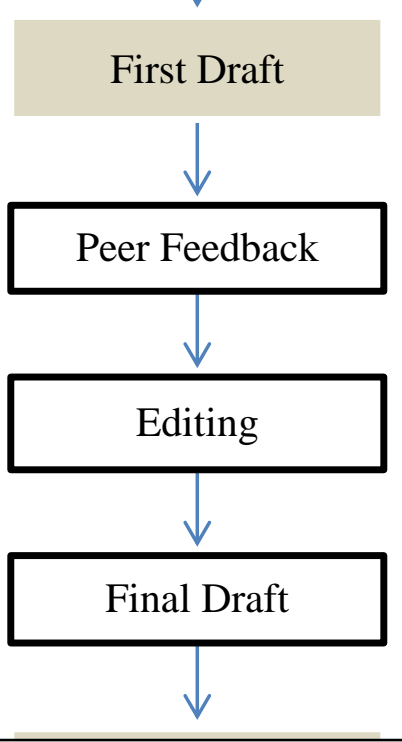




This practice coincides with Chow's (2007) where he stated that, writing instruction in Malaysian writing classroom is still very much product oriented. In this study, the pre-service teachers' practices showed that they applied process approachonly to enhance the application of product approach. Some earlier studies also confirm this issue where they found some discrepancy between the teacher's knowledge and actual classroom teaching practices (Mahaletchumy, 1994). Moreover, it was also found that the brainstorming, planning and mind mapping strategies were not utilized appropriately to trigger the students cognitive towards independent writing. Consequently, students did not benefit from the strategies of process approachwhich were carried out occasionally. Thus, the students may develop passive writing techniques by regurgitating the input provided by the pre-service teachers. Although, students may seem to be able to write to a certain extent, this habit may prevent them to be creative writers and their higher order thinking skills will not be tapped or developed. Thus, there is a high tendency of producing dependent writers with less creativity and critical thinking ability.

\subsection{Conclusion}

The results of the study indicated that the pre-service teachers preferred to employ product approach to teach writing lessons to the primary students. Most of the written works prepared by the students show that they have written according the requirements. The requirements were prepared by the pre-service teachers according to the topics, skills and topics planned for the particular lesson. The aims of the pre-service teachers were to ensure that their students have mastered the particular objectives set for the day. Basically, the pre-service teachers were found to provide some input to the students in the beginning of the lesson. Then, the teachers prepared some similar practices for the students to conduct in the class which was very controlled. And finally, the students had to produce a piece of writing which is similar to the topic that was introduced in the beginning of the lesson. Thus, the students were found to produce the final piece of writing using the same sentence structure, vocabulary and style. All these activities indicate the first three stages (strategies) of product approach. Thus, the first research question of this study was answered which shows that the pre-service teachers have adopted the product approach as the main writing instruction to teach in the ESL primary ESL classrooms.

The study also found that there were a small number of the pre-service teachers who tried to include brainstorming and mind mapping strategies which resemble some stages of the process approach. However, these activities were found to be conducted to complement the product approach where the students still had to produce a similar task by the end of the lesson. Thus, the other important stages of process approach such as editing and redrafting stages were not found be practised. This is due to the main challenge of time constraint as the teachers had to comply with the requirements of the syllabus of the subject.

The practises of the pre-service teachers who participated in the study showed that they have employed product approach widely especially the first three stages of the product approach. They were also found to have included the practice of brainstorming and mind mapping to some extent. Thus, the pre-service teachers' practices may help students to prepare writing instantly which can be considered successful in achieving the day to day objectives of the writing lesson. However, the pre-service teachers need to try to implement the more crucial part of the writing approaches to prepare students to be independent writers. Thus, the second research question of this study was answered which highlights the impact of the chosen approaches and strategies on students' writing ability in the short and long term.

In conclusion, the teachers may have to practice more strategies (or stages) of process writing such as preparing several drafts before the final drafts and involve students in editing their friends' work in order to produce more independent writers. In this way, students can be involved in the writing activities more than learning the input provided by their respective teachers.

\subsection{Recommendations:}

The study would like to suggest several recommendations to make writing lessons for appealing and meaningful:

- Include free writing of product approach in writing lessons

- Inculcate drafting habits among students and involve several drafts before submitting the final draft.

- Involve students in the editing processes and redraft according to the corrections suggested

- Include more in-class writing activities rather than teachers' input

\subsection{Sponsoring information -}

Acknowledgement: The funding for this publication was provided by UTHM TIER 1 Grant (H193) 


\section{References}

Al-Sawalha, D. A. M. (2014). Potential Advantages of Process Writing For Students. English Language and Literature at Jerash University in Jordan.

Badger, R. and White, G. (2000). A process genre approach to teaching writing. ELT Journal, 52(2), 153-160.

Chow V. F. T. (2007). The Effects of the process-genre approach to writing instruction on the expository essays of ESL students in a Malaysian secondary school. Unpublished doctoraldissertation. Kuala Lumpur, Malaysia.

Hilmi, F. H., Ramayah, T., Mustapa, Y. \&Pawanchik, S. (2010). Product and Process innovativeness: Evidence from Malaysian SMEs. European Journal of Social Sciences. 16(4), 556-565

How, S. Y., Heng, C. S., and Abdullah, A. N. (2015). Language Vitality of Malaysian languages and its Relation to Identity. GEMA Online ${ }^{\circ}$ Journal of Language Studies, 15(2).

Majid Pour-Mohammadi, Mohamad JafreZainolAbidin and Cheong, L. F., (2012). The Effect of Process Writing Practice on the Writing Quality of Form One Students: A Case Study. Asian Social Science, 8(3), 88-99.

Mahaletchumy, N. (1994). What do ESL teachers do when they say they are teaching writing? Unpublished M.Ed. Thesis, University of Malaya

Mukundan, J., Mahvelati, E. H., Mohd Amin Din and Nimehchisalem, V. (2013). Malaysian Secondary School Students' ESL Writing Performance in an Intensive English Program. World Applied Sciences Journal, 22(12), $1677-1684$.

Ramadi, E., Ramadi, S., \& Nasr, K. (2016). Engineering graduates' skill sets in the MENA region: a gap analysis of industry expectations and satisfaction. European Journal of Engineering Education, 41(1), 34-52.

Sahin, C., Bullock, K. and Stables, A. (2002). Teachers' Beliefs and Practices in relation to their Beliefs about Questioning at Key Stage 2. Educational Studies. 28(4), 371-384.

Steel, V. (2004). Product and process writing. Retrieved on 10 Mac 2013 from http://www.teachingenglish.english.org.uk/think/write/approaches.html

Suryasa, I. W., Prayoga, I., and Werdistira, I. (2017). An analysis of students motivation toward English learning as second language among students in Pritchard English Academy (PEACE). International journal of social sciences and humanities, 1(2), 43-50.

Ting, S.-H., Marzuki, E., Chuah, K.-M., Misieng, J., and Jerome, C. (2017). Employers'views On Importance Of English Proficiency And Communication Skill For Employability In Malaysia. Indonesian Journal of Applied Linguistics, 7(2), 315-327.

Williamsa, C. \&Beamb, S. (2019). Technology and writing: Review of research. Computers \& Education. 128, 227242. 